\title{
Membunuh Tradisi’: Adegan Musik Metal Dan Subkultur Madura
}

\author{
Ardhie Raditya \\ Fakultas Ilmu Sosial Dan Hukum, Universitas Negeri Surabaya, Jl. Ketintang, Surabaya, 60213 \\ E-mail: diditz.kristina@gmail.com; ardhieraditya@unesa.ac.id
}

\begin{abstract}
Metal music is not 'easy listening' music. Unlike pop music which is full of "laziness", metal music is full of "explosions" from a musical aspect so, not everyone is able and willing to explore metal music. Because of its aggressive noise, metal music is flourishing in the big cities. Madura, whose society tends to be traditional, is a serious obstacle for its young people who enjoy metal music. Those who enjoy metal music are commonly referred to as "metal youths". So far, there have not been many metal studies in Madura. In fact, Madurese metal youths performed metal music scenes that were no less great than those of outsiders. Therefore, this study seeks to describe scenes of obedience to Madurese metal youths with a musical phenomenology approach, and to explain them from the perspective of subcultural studies. Based on the results of the research, it shows that the scenes of the metalization of Madurese metal youths are not only centered on the musical scene, but also, jump out of the musical scene which shakes the stability of the tradition and the political domination of their religion.
\end{abstract}

Keywords_-: Metal Music Scenes; MadureseMetalYouths; Subcultural Studies.

\section{PENDAHULUAN}

Madura sebagai daerah surplus seni musik menyita perhatian sejumlah peneliti luar Madura. Pada umumnya, seni musik tradisional dan keagamaan masyarakatnya menjadi sumber utama topik penelitian mereka. Bouvier (1989: 207) menyebutkan bahwa di Sumenep tergolong kawasan paling kaya dan aktif musik tradisional dan bentuk seni pentasnya, seperti, orkes, tari, teater, dan bela diri. Padahal, sejak kemerdekaan Indonesia, keroncong dan dangdut mulai mengganggu stabilitas musik tradisional karena membawa unsur musikalitas barat (Frederick, 1982; Yampolsky, 1991; Ferzacca, 2006), seperti tercermin dari penggunaan alat-alat musik berteknologi, tangga nada diatonik, media massa, sistem bebunyian sonikal, dan gaya penampilan rombongan pementasnya. Situasi ini segera memicu minat serta intensitas selera para kawula mudanya terhadap jenis musik barunya. Penelitian Becker (1975) menengarai bahwa istilah keroncong kemungkinan besar berasal dari istilah klintingan yang diikat pada pergelangan kaki penari muda rèmo Madura dan menginspirasi pemain keroncong, baik di Batavia maupun seluruh pesisir Jawa, pada permulaan abad ke-20.

Kedua jenis orkes musik yang relatif baru tersebut menunjukkan pola hidup perkotaan (baik Surabaya maupun Sumenep), terutama di kalangan kawula mudanya, sebagai satu kesatuan koheren karena kedekatannya dengan akar sejarah melayu modern (Bouvier, 2002: 87-91). Pasca dekade 70-an, eksistensi keroncong mulai meredup, tetapi, memperkuat eksistensi dangdut di seluruh Madura, terlebih lagi, sebagian besar orkes-orkes dangdutnya memasukkan unsur kebahasaan Madura. Artis-artis nasional di belantika industri musik dangdut berangsur-angsur berdatangan dari Sumenep, dan menjadi idola baru Indonesia menyamai popularitas Rhoma Irama, semisal, Imam S. Arifin, Jhonny Iskandar, dan Yus Yunus. Itulah sebabnya, Sumenep disebut-sebut hingga kini sebagai kota dangdut Madura.

Namun, sejumlah penelitian musik di Madura belum memperhatikan secara serius, bahkan, mendalam mengenai kemunculan dramatis musik metal yang dibawakan kawula muda (yang mereka lebih dikenal dengan julukan "anak metal") Madura. Musik metal merupakan label yang disematkan terhadap kebangkitan genre musik rock yang berkembang pesat di berbagai penjuru dunia pada pertengahan abad ke-20 (Covach, 1997; Shuker, 1994). Musik metal sebagai kepanjangan tangan budaya rock identik dengan ritual 'penyimpangan', meledak-ledak secara musikalitas, memekakkan telinga, dan atraksi kebrutalan sebagai artikulasi pemberontakan telah membedakan dari keluhuran tradisi musik generasi tuanya (Witkin, 2003). Pada dekade 30-an, musik metal secara kultural lebih dekat dengan musik rock ' $n$ roll yang berkembang pesat di perkotaan Inggris sebagai representasi kelompok anak muda yang menyukai balapan liar atau budaya kebut-kebutan. Sehingga, musik yang digemarinya cenderung musik beritme cepat serta berdentum keras sebagai penyaluran sensibilitas budaya profan mereka (Willis, 2014). Selama empat dekade, sejak memasuki era 70-an, musik metal sebagai kluster musik rock bertransformasi menjadi musik transnasional. Musik ini awalnya tumbuh subur di Amerika dan Eropa, tetapi, berkat kekuatan industri musik kehadirannya terus menyebar luas hingga era 1980-1990-an merambah ke Asia, seperti, Jepang, Malaysia, dan Indonesia (Wallach, Berger, dan Greene, 2011).

Tak jarang penggemar musik metal merasa diri mereka seakan terhina dan tidak nyaman jika disanding-sandingkan dengan musik rock. Dann Saladin, misalnya, musisi metal dari band “The Final Silencing” menganggap bahwa musisi atau bintang rock cenderung berjarak dengan penggemarnya dan berorientasi komersil, suatu fenomena musikal yang ditolak kalangan musisi atau bintang musik metal (Berger, 1999). Metal tidak sama dengan musik rock yang menerima musik pop, karena metal 
fundamental lebih dekat dengan 'thrash' atau 'speed' metal (Weinstein, 2000). Pada metal terdapat sub-genre yang berbeda dari rock karena kemunculan death metal yang lebih tepat disebut sebagai metal ekstrem. Adegan-adegannya aggresif: vokal sulit dicerna dan disimak (less and less intelligible), penulisan lagunya kompleks, pukulan gitar dan kunci nadanya rumit, serta gaya penampilannya yang 'dark' (Kahn-Harris, 2007). Death metal dikembangkan dari aliran black metal atau dikenal 'aliran baru heavy metal British' yang tenar ketika era 60 - 70-an berkat band sekelas Black Sabbath, Deep Purple, dan Led Zeppelin. Musik ini berinkarasi berkat aliran death metal Florida di Amerika sejak dekade 80 - 90-an, yang memunculkan band sekelas Obituary, Morbid Angel, Canibal Corp, Atheist, Nocturnus, Brutality, Killing Addiction, dan lainnya. Musik metal Florida ini mempunyai ciri khas gaya New York death metal (New York Style of Death Metal) yang disebut suffokasi (mati lemas atau gaya pementasan 'kekurangan nafas'). Yakni, mutilasi pendek atau tranposisi akord-akord gitar dengan mengandalkan kecepatan jari dan keterampilan tangan agar menghasilkan suara 'deep' gitar, jeritan atau suara parau vokal, teknik pedal ganda (double pedal) drum yang cepat, sehingga pemainnya menampilkan otot-otot mereka yang kekar dan raut muka yang sangar. Kesemua gaya death metal ini memacu penggemarnya bertari-tari 'kesurupan', baik berbentuk moshing maupun head banger (Purcell, 2003). Apabila, seni musik tradisional kental dengan suara ning-nong-ning-gung, dan suara musik modern berupa jrang-jreng-jring-jreng (Mrázek, 1999: 49) maka, musik metal menggaungkan suara jepp-jepp-grubak-grubuk.

Sebagai pelaku, penggemar, pemerhati, dan promotor rock serta metal di Madura, peneliti mengamati bahwa perjalanan hidup dan akar sejarah kebisingan musik aggresif ini berasal dari kota Pamekasan. Celakanya, laporan riset keseniaan yang dilakukan oleh Bappeda Pamekasan (2019), Raditya (2016), dan dokumentasi sejarah yang tertuang dalam tulisan Ensiklopedi Pamekasan (2010), belum memberikan catatan sedikit pun pada keberadaan musik rock, apalagi, musik metal. Padahal, kota ini lebih dekat hubungannya dengan kota pelajar maupun pusat pendidikan terbaik di Madura, sehingga budaya populer, termasuk, musik populer anak mudanya lebih aktif dan kaya.

Secara kuantitas, berdasarkan data BPS Provinsi Jawa Timur pada tahun 2020 menunjukkan siswa SMA di Pamekasan berjumlah 13.703, di Sumenep 14.472 siswa, di Sampang 12.618 siswa, dan di Bangkalan 16.398 siswa. Di SMK, total siswanya 13.966 siswa di Pamekasan, di Sumenep 7.383 siswa, di Sampang 10.681 siswa, dan di Bangkalan 14.288 siswa. Pada jenjang MA jumlah siswa di Pamekasan sebanyak 17.829, di Sumenep 15.313 siswa, di Sampang 10.695 siswa, dan di Bangkalan 8.778 siswa. Jumlah mahasiswa yang pada umumnya berasal dari kawasan Madura dan berkuliah di berbagai kampus swasta di Pamekasan sebanyak 7.575 orang, di Sumenep 5.288 orang, di Sampang 357 orang, dan di Bangkalan 2.632 orang. Tahun 2010, Menteri Pendidikan menobatkan Pamekasan sebagai kota pendidikan karena banyak pelajar di Pamekasan meraih penghargaan bergengsi di level internasional. Jauh sebelum itu, musik rock mulai dipopulerkan hingga menjelajah seantero Madura berkat kepiawaian bermusik anak muda Pamekasan yang duduk di bangku sekolahan, pada era 60-an, dan mereka tergabung ke dalam band legendaris sepanjangan masa, 4 Bayangan (Raditya, 2019). Mengacu data yang peneliti miliki tentang tiga panggung kompetisi prestisius berkonotasi rock yang dihelat di pusat kota Pamekasan (1998, 2002, 2005) atas sponsor Sampoerna dan Djarum (keduanya perusahaan rokok yang sering membuat acara musik anak muda di Madura), dari semua peserta dan juaranya terlihat bahwa musisi rock Pamekasan cenderung mendominasinya (lihat tabel 1.). Itulah sebabnya, kota Pamekasan bukan sebatas kota pendidikan, melainkan juga, kota Rocker Madura.

Tabel 1. Peserta ${ }^{1}$ dan Juara Festival Rock di Madura Tahun 1998, 2000, dan 2005

\begin{tabular}{|c|c|c|c|c|c|c|c|c|}
\hline \multicolumn{3}{|c|}{ Festival Rock Se-Madura 1998} & \multicolumn{3}{|c|}{ Festival Rock Se-Jawa Timur 2002} & \multicolumn{3}{|c|}{ Parade Musik Indie 2005} \\
\hline Peserta & Asal & Juara Umum & Peserta & Asal & $\begin{array}{c}\text { Juara } \\
\text { Umum }\end{array}$ & Peserta & Asal & $\begin{array}{c}\text { Juara } \\
\text { Umum }\end{array}$ \\
\hline 80 Band & $\begin{array}{l}\text { Bangkalan } \\
\text { (10 band) } \\
\text { Sampang } \\
\text { ( } 10 \text { band) } \\
\text { Pamekasan } \\
\text { ( } 40 \text { band) } \\
\text { Sumenep } \\
\text { ( } 20 \text { band) }\end{array}$ & $\begin{array}{l}\text { Pamekasan } \\
\text { (Dari } 10 \\
\text { piala, peserta } \\
\text { asal } \\
\text { Pamekasan } \\
\text { memperoleh 6 } \\
\text { piala) }\end{array}$ & $\begin{array}{c}100 \\
\text { Band }\end{array}$ & $\begin{array}{l}\text { Surabaya } \\
\text { (10 band) } \\
\text { Malang } \\
\text { ( } 10 \text { band) } \\
\text { Bangkalan } \\
\text { ( } 15 \text { band) } \\
\text { Sampang } \\
\text { (15 band) } \\
\text { Pamekasan } \\
\text { (30 band) } \\
\text { Sumenep } \\
\text { ( } 20 \text { band) }\end{array}$ & $\begin{array}{l}\text { Pamekasan } \\
\text { (Dari } 10 \\
\text { piala, } \\
\text { peserta asal } \\
\text { Pamekasan } \\
\text { memperoleh } \\
4 \text { piala) }\end{array}$ & $\begin{array}{c}100 \\
\text { Band }\end{array}$ & $\begin{array}{l}\text { Surabaya } \\
\text { (15 band) } \\
\text { Malang } \\
\text { (15 band) } \\
\text { Bangkalan } \\
\text { ( } 15 \text { band) } \\
\text { Sampang } \\
\text { (15 band) } \\
\text { Pamekasan } \\
\text { ( } 25 \text { band) } \\
\text { Sumenep } \\
\text { ( } 15 \text { band) }\end{array}$ & $\begin{array}{l}\text { Pamekasan } \\
\text { (Dari } 10 \\
\text { piala dan } \\
\text { quota lagu } \\
\text { indie yang } \\
\text { direkam, } \\
\text { peserta asal } \\
\text { Pamekasan } \\
\text { memperoleh } \\
5 \text { piala) }\end{array}$ \\
\hline
\end{tabular}

Setiap panggung rock digelar biasanya segera dibuntuti munculnya rombongan anak metal di kanan-kirinya. Gambaran sekilas yang sering diutarakan guru-guru musik di sekolah, semisal, bang Joni, atau personel Power Metal dan anggota CB Band Kediri, hampir memiliki kesamaan pandangan. Menurut mereka, di Pamekasan dari 10 anak muda yang berkumpul 5 di

\footnotetext{
${ }^{1}$ Tidak semua peserta hadir pada waktu kompetisi karena tiga alasan. Pertama, alasan teknis seperti, dinyatakan gugur karena telat hadir. Kedua, alasan transportasi dan penginapan. Biasanya, peserta yang terkendala masalah ini berasal dari luar Madura. Pada saat itu, menuju ke Madura harus melewati laut menggunakan kapal feri dari pelabuhan perak-kamal. Hotel-hotel terbaik di kota Pamekasan juga belum sebanyak dan semewah sekarang. Ketiga, alasan mendongkrak popuralitas karena lebih memilih tampil di kompetisi lain yang tidak banyak pesertanya dan berpeluang band mereka menjadi pemenang. Selain itu, sebagian memilih memenuhi undangan menjadi bintang tamu di acara hiburan lain. Karena, perhelatan kontestasi musikal di Madura rata-rata diadakan pada sabtu dan minggu. Ketidakhadiran peserta kompetisi musik karena ketiga alasan ini membuat jumlah band dari masing-masing kota menyusut hingga $30 \%-50 \%$ dari total peserta.
} 
antaranya rocker, 3 orang tergolong anak metal, dan sisanya penggemar musik pop atau kadangkala salah satunya diam-diam juga penggemar berat dangdut. Menurut Wallach (2008: 232-233) musik metal di kota besar seperti, Jakarta dan Bandung, merupakan peristiwa diversitas aposteriori karena adanya adegan yang belum pernah terjadi sebelumnya. Yakni, panitia yang rata-rata dari kalangan pelajar, mahasiswa, atau juga gabungan keduanya, menggelar acara musik satu genre atau sub-genre dalam satu panggung supaya menambah keramaian dan kemeriahan acara, serta berpotensi meraih berlipat-lipat profit ekonomi. Tak seperti di kota besar ini, kelompok band metal, punk, dan musik underground di Bali tidak hanya sebatas genre musik, melainkan juga, berdimensi visual dan spasial. Menurut Baulch (2007: 22-23) ketiga kelompok musik itu memiliki teritorial dan pandangan relasi gender berbeda di ruang publik. Sebagai bagian industri wisata dunia, anggota punk dan underground menjadikan mall dan jalanan di Bali sebagai sarang berkumpul mereka, tetapi, tidak dengan kelompok metal. Laki-laki dari kelompok mereka suka melontarkan godaan kepada perempuan muda 'nakal' dan 'liar' melalui wacana agresif mereka. Sebaliknya, kelompok metal menghabiskan waktu berkumpulnya di studio musik dan outlet kerajingan tangan mereka agar perempuan muda merasa aman di ruang publik. Walaupun demikian, kelompok punk dan metal Bali sama-sama tidak antusias pada menjamurnya 'cewek matre'. Sebab, kultur komersialisme dan hedonisme Jakarta telah merasuki mereka. Kedua komunitas musik ini juga mencela budaya komersial komunitas underground Bali dalam bermusik.

Anak metal Madura secara konteks sosial dan kultural memiliki perbedaan yang kontras dari kehidupan kota-kota besar sebagaimana dialami anak metal di Jakarta, Bandung, dan Bali. Perhatian, pemahaman, dan penjelasan konteks sosial dan kultural bagian penting dari adegan (scene) musikal. Istilah "scene" mulai populer di dunia sekitar tahun 1940-an karena sering dipakai oleh para jurnalis musik untuk menggambarkan musik bawah tanah kulit hitam, Jazz, sebagai gaya hidup baru kaum Bohemian. Para akademisi bidang kajian budaya, sosiologi, dan disiplin ilmu sosial berbasis musikal lainnya yang ber(o)posisi di luar lingkaran disiplin musikologi memakai istilah "scene" berdasarkan konsep berbeda-beda dalam kaitannya dengan 'panggung' atau dunia musik lokal, translokal, dan virtual (Peterson dan Bennett, 2004). Untuk para sarjana dan akademisi musik populer, Straw (1991 dan 2004) memberikan pegangan konseptual bahwa "scene” diartikan ruang geografis spesifik sarat sensasi yang mengartikulasikan beragam praktik musikalitas, sosiabilitas, dan visibilitas sosial sebagai teater urban (misalnya, restoran, cafe, dan kumpulan orang-orang), dan morphologi sosial (misalnya, dunia seni, subkultur, atau organisasi).

Sebagai ekspresi gagasan, perasaan, keterampilan, mobilisasi, estetika, dan produksi budaya yang berelasi dengan segala aspek kehidupan masyarakat, sulit mengisolasi proses penciptaan musik rock (making-rock music) beserta kekayaan aliran di dalamnya dari proses produksi "scene" (making-scene). Cohen (2007), misalnya, melalui hasil penelitian musik rock di Inggris menunjukkan pengaruh "Liverpol Scene" bagi keberlangsungan hidup musik popular tersebut yang terbentuk oleh kekuataan budaya klub dan bohemian urban, sehingga, berdampak langsung terhadap kebisingan kota, wisata, maupun regenerasi musisi serta penggemar musiknya. Budaya klub di Inggris ini merupakan tempat sosial bagi kawula muda karena menunjukkan simbol statusnya sebagai orang dewasa yang tak ingin kesenangannya dikontrol orang tuanya, industri kesenangan yang membuat mereka kerasan seakan tinggal di 'rumah sendiri', pusat perubahan dan pertunjukan trend pakaian, serta klub memfasilitasi kumpulan selera seperti musik, seksualitas, hingga intoksinasi legal yang terjangkau (Thornton, 1995: 18-22).

Budaya klub di Austin, Texas, yang berimbas terhadap produksi “scene” rock n' roll bukan sebatas dorongan kesenangan, namun juga, kecemasan sebagai ketidakkekalan momen identifikasi dari pertukaran tanda antar simpul anggota komunitas dalam bentuk obrolan, pakaian, musik, dan tarian yang berakibat "subjek selalu berproses" serta terasing jika tidak hadir di klub (Shank, 1994: 131). Maka, "scene” mungkin lebih tepat diartikan sebagai adegan yang relasional secara holistik dan investigatif tentang topik-topik musik dan latar kehidupan yang melingkupinya. Ia ibarat pendulum yang menggerakkan detak perubahan jarum jam. Adegan metal, sebagai contoh pendekatan holistik dan pemetaan, dapat berwujud dua partikular ruang yaitu, keterasingan sebagai 'adegan yang baik', dan pertemanan sebagai keanggotaan komunitas (Kahn-Harris, 2007: 14). Oleh karena itulah, tulisan ini dibuat sebagai upaya mendeskripsikan adegan musik metal di kalangan anak metal Madura.

\section{METODE PENELITIAN}

Fenomenologi musik berupaya menggali kesadaran subjek yang terlibat dalam relasi antara ruang dan waktu, panggung spektakuler, dan interaksi sosial sehingga, menciptakan makna radikal tentang pengalaman, pengetahuan, kesejarahan, maupun pandangan politik yang berpengaruh pada suatu komunitas musikal (Mazzoni, 2010: 225-226, Berger, 1999: 254-255). Fenomenologi musikal mengganggap musik sebagai praktik berbahasa, sehingga, musik dipahami sebagai teks budaya yang menyimpan praktik signifikansi budaya (Monelle, 1992), dan praktik budaya ini perlu melihat posisi kelas dan kedudukan seseorang dari sudut pandang objektif dan subjektif yang melegitimasi maupun menginterupsi budaya yang terstruktur (Bourdieu, 1991: 232). Pendekatan kualitatif ini memerlukan 'teoritisasi' yang berusaha mendeskripsikan dunia dari bahasa dan sudut pandang orang setempat terhadap situasi, peristiwa, dan proses sosial spesifik yang saling terkait (Maxwell, 2013). Karena itu, penelitian musik metal di kalangan anak metal Madura menggunakan fenomenologi kritis musik ini sehingga, berkontribusi bagi perkembangan studi metal di kawasan masyarakat kota kecil, pinggiran. Dengan keistimewaan perspektifnya di 'level mikro' mungkin saja menjadi perspektif 'tandingan' dari studi metal arus utama yang cenderung berfokus di kota-kota besar atau metropolitan.

Penelitian ini dilakukan di Madura dengan memusatkan penggalian data di kota Pamekasan dengan tiga pertimbangan. Pertama, secara geografis, letak kota Pamekasan berada di tengah pulau Madura dan jaraknya jauh dari kota besar seperti, Surabaya dan Jakarta. Tetapi, sejak dahulu kota Pamekasan dikenal pusat pemerintahan negara Madura. Banyak peninggalan artefak-artefak budaya modern yang digunakan sebagai adegan-adegan musik populer yang dekat dengan kehidupan anak 
mudanya. Kedua, dibandingkan kota-kota lain di Madura, Pamekasan merupakan pusat pendidikan di Madura sehingga, kehidupan musik anak mudanya bergairah. Ketiga, pasca orde baru, musik anak muda menghadapi ancaman 'pembunuhan' massal dari rezim politiknya atas dalih agama sehingga, pada momen tertentu ketegangan antara 'orang tua' Madura dan anak mudanya tidak terhindarkan.

Berbagai data pada penelitian ini diperoleh melalui wawancara, observasi, dan dokumentasi. Sebagai pelaku musik yang telah menjelajah dari kota ke kota, baik di dalam maupun di luar Madura, proses wawancara dengan para informan utama (anak metal dan 'orang tua' Madura) tidak banyak mengalami kendala budaya. Persoalan teknis muncul karena mobilitas yang tinggi di kalangan anak muda Madura. Peneliti mau tidak mau harus membagi waktu untuk menemui mereka secara berkala di hampir seluruh Madura dan luar Madura. Hal ini sedikit membocorkan kantong pribadi yang tidak pernah mendapatkan asupan dana sponsor dari pihak manapun. Selama berburu data wawancara, observasi terlibat dilakukan tanpa merasa risih, sungkan, atau terancam pandangan sinis masyarakat sekitar. Karena, peneliti sebagai bagian dari 'orang dalam' memahami cara mengatasinya. Sekalipun situasi ini menguntungkan, peneliti harus tetap 'menjaga jarak' dengan lingkungan sekitar agar data lapangan yang diperoleh lebih akurat dari sisi metodologis. Sedangkan, data dokumentasi diperoleh dengan teknik korpus material untuk mengkonstruksikan dan merefleksikan peristiwa sejarah yang mungkin tidak ditemukan pada teknik wawancara dan observasi (Flick, 2007: 32). Teknik korpus ini dilakukan dengan melacak dokumentasi ke berbagai tempat, orang relevan, dan kumpulan tekstual secara selektif yang berada di satu ruang penelitian atau di ruang penelitian berbeda. Dengan begitu, keabsahan data bukan menyangkut 'ketebalan' atau 'kedangkalan', tetapi, pada diferensiasi budaya yang terdiri dari potongan-potongan yang dirangkai holistik supaya hasil kerja lapangan 'multi-lokasi’ tersaji cukup memadai (Falzon, 2009).

\section{III.HASIL DAN PEMBAHASAN}

\section{A. Madura 'Brutal' Dan Subkultur Madura}

Studi-studi masyarakat Madura, selama ini, yang terpublikasi secara luas dan menjadi bahan literasi arus utama acapkali memposisikan Madura sebagai daerah minus serta tertinggal dari daerah tetangga dekatnya, seperti Surabaya, Malang, dan sekitarnya. Tulisan peneliti dari Belanda, De Jonge (1989 dan 2011), misalnya, hampir tidak pernah memberikan ruang istimewa secara holistik tentang kesuksesan dan kabar baik orang Madura dalam upayanya mengubah 'takdir' ketertinggalannya dari Jawa. Datangnya publikasi penelitian Kuntowijoyo (1993 dan 2002) memberikan sedikit pencerahan dalam memahami Madura sebagai daerah yang sudah lama terpecah belah sejak masuknya kolonial ke Madura sehingga, Madura sulit terintegrasi ke dalam politik, ekonomi, dan budaya nasional. Sejak jembatan Suramadu dirancang dan dibangun sebagai program pembangunan nasional, Kuntowijoyo (1995) mencatat pengalaman lapangannya yang mengejutkan tentang loncatan Madura ke luar dari ketertinggalannya, karena, tanah di Bangkalan, daerah penyanggah jembatan Suramadu di Madura, mulai banyak ditawarkan oleh orang Cina untuk dijual.

Namun, berbagai penelitian orang luar Madura tersebut absen dari kajian subkultur Madura yang mengkaitkan pada kehidupan anak-anak mudanya terhadap perkembangan globalisasi budaya, terutama, musik rocknya (Raditya, 2019 dan 2002). Kajian subkultur diasosiasikan dengan salah satu topik utama dalam kajian budaya (cultural studies) mazhab Birmingham di Inggris sebagai fenomena baru masyarakat modern pasca perang dunia kedua dengan kemunculan kelas pekerja dari kalangan anak-anak muda. Terminologi subkultur berhubungan dengan kelas budaya sebagai subordinasi dari budaya orang tua dan nilai tradisional yang terlokalisir serta terstruktur ke dalam kelompok berskala kecil yang kapasitasnya membesar karena jaringan mereka satu dengan lainnya (Clarke, dkk., 1993). Popularitas subkultur ini terus meluas dengan konotasi negatif oleh pemberitaan media massa yang terkooptasi elit politik dan rezim penguasa untuk menciptakan 'musuh bersama' terhadap kelompok anak muda yang melanggar norma dan menyulut kepanikan moral sehingga, membuat instabilitas tatanan sosial yang telah hidup mapan (Thornton, 1997; Cohen, 2002). Padahal, kelompok subkultur menekankan diferensiasi relatif, derajat komitmen, hingga operasi otonomi anak-anak muda sebagai ekspresi spontanitas mereka terhadap situasi kontradiksi struktural, atau juga resistensi terhadap kepalsuan media dan institusi pendukung lainnya yang berorientasi profit (Hodkinson, 2002). Secara interaksionisme simbolik, subkultur sebagai labelisasi terhadap kelompok devian yang gemar mabuk seperti, musisi jazz di Amerika (Bekcer, 1963), kelompok gengster dan para lelaki yang menyimpang (abnormal) dari integrasi standar normalisasi masyarakatnya (Cohen, 1955). Dan, kelompok terasing (subterranian) yang bereaksi keras pada konfirmitas tatanan birokrasi, totalitas strata sosial, rutinitas sosial yang menjenuhkan, dan fatalisme masyarakat melalui tindakan aggresif, kesenangan, sekaligus hiburan seperti yang dilakukan kelompok rocker dan anak muda modern (Young, 1997). Respon dari subkultur terhadap situasi dominasi, budaya konsumsi, dan kelas dominan di sekitar masyarakatnya menampilkan gaya subkultur yang subversi, meneguhkan simbol solidaritas, hingga mendistorsi citra diri dari publik general untuk mendapatkan ruang kemenangan di sudut jalan, pusat keramaian dan hiburan, serta sekitar pertetanggaan mereka (Hebdige, 1979 dan 1997; Clarke, dkk., 1993) sebagai kekuatan gerak hidup sehari-harinya (Grossberg, 1997) maupun kemandirian ekonomi kelompoknya yang menunjukkan kekuatan budaya tandingnya (McRobbie, 1989).

Sebagaimana umumnya orang Madura, anak muda Madura sangat menjungjung tinggi nilai-nilai kesopanan, kehormatan, dan tata krama dalam menjalin hubungan kekeluargaan, pertemanan, pendidikan, dan keagamaan. Keluhuran nilai-nilai hidup orang Madura tersebut biasa dikenal dengan istilah tèngka. Tèngka tidak hanya bertujuan untuk menjaga tertib sosial, keharmonisan, dan upaya saling menjaga keselamatan hidup, baik di antara sesama orang Madura maupun antar orang luar Madura. Melainkan juga, menjaga pelapisan sosial yang hidup mapan di Madura seperti tercermin dari bahasa adiluhur tentang 
trilogi orang tua (rèng towah) Madura: bhuppa'-bhâbhu', ghuru, ratoh (orang tua, guru, dan pemimpin). Karena itulah, tèngka menjadi pedoman hidup ideal orang Madura yang tidak tertulis, namun, mengikat sepanjang hidup mereka. Mengingkari prinsip tèngka membuka kemungkinan munculnya suasana perselisihan, pergolakan, dan persengketaan di antara sesamanya. Pada kondisi yang teramat parah, urusan tèngka ini akan memicu terjadinya carok, yakni, duel satu lawan satu menggunakan clurit setelah di antara para pelakunya menggelar konsensus keluarga dan mendapatkan legitimasi tokoh sentral keagamaan mereka (kiai) (Wiyata, 2002). Dengan demikian, tata krama orang Madura bersifat temporal, kondisional, dan mempertebal ritual aggresif mereka. Ritual aggresif ini merupakan seremoni kebrutalan manusia sebagai transmisi budaya yang mengacu pada tiga ciri utama masyarakat tradisional. Yaitu, insting bertahan hidup dari segala ancaman atau serangan pihak lain, menjaga kehormatan figur kelaki-lakian sebagai penjaga tatanan hidup berjalan baik (Konrad, 2002), dan mediator altruisme untuk menyelamatkan martabat diri dan kelompoknya (Zahn-Waxler, dkk., 1986). Aggresi yang destruktif juga bisa terjadi pada seseorang yang mengalami keterasingan dari interaksi eksistensial dalam hubungan sosial karena hendak merenggut kedaulatan orang lain atau menonjolkan kapasitas diri defensif pada orang lain (Fromm, 1973). Maka, kondisi tertentu, tata krama berpotensi merekatkan hubungan, meredam perselisihan, namun, pada kondisi lainnya, memperkeruh hubungan sosial, merusak kekerabatan, dan memutus tali pertemanan orang Madura.

Namun, carok terlanjur menjadi label menjengkelkan yang sering diprasangkakan orang luar Madura terhadap siapa pun yang berasal dari Madura sehingga, kadangkala mengisolasi mereka dari hubungan keintiman dengan orang lain di luar Madura. Padahal, tidak semua persoalan akan segera mendorong terjadinya peristiwa carok. Karena, Carok fundamental terjadi ketika seorang laki-laki mengganggu perempuan yang terikat hubungan sakral dengan lelaki Madura (Wiyata, 2002). Media massa kadangkala seringkali membesar-besarkan peristiwa carok sebagai 'kebanggaan' tradisi orang Madura tanpa memperdalam tinjauan sosiologis maupun antropologis. Padahal, carok sulit terjadi di kalangan anak muda Madura karena, menurut Rifai (2012: 21) pendidikan nasional yang menjangkau Madura berhasil menanamkan budaya toleransi kepada anak-anak muda Madura.

Perkelahian di antara anak muda Madura, sebagaimana halnya terjadi juga di daerah lainnya di Indonesia, biasa dikenal dengan istilah atokar (berkelahi atau tawuran). Peristiwa perkelahian di antara anak muda ini sangat rahasia karena tidak ingin orang tua, guru, atau keluarga dekat mereka tahu karena bisa mencemarkan nama baiknya. Peristiwa perkelahian rocker Madura paling dramatis terjadi di era 60-an. Waktu itu, band empat bayangan memasuki masa keemasan. Mereka manggung atas undangan panitia untuk mengisi resepsi pernikahan, ulang tahun, pesta seni sekolah, peresmian proyek pembangunan, dan harihari penting perayaan nasional. Ketika band ini bersama band rock AKA Surabaya tampil di acara pernikahan pejabat teras di salah satu kota Madura, anggota band lain melemparinya dengan kotak berisi sampah makanan dan mengenai Ucok, vokalis AKA. Karena tidak terima temannya disakiti, anggota band Empat Bayangan memburu pelakunya dan pesta pernikahan berakhir tawuran di antara mereka. Peristiwa perkelahian antar rocker Madura ini berlangsung lama hingga memasuki pertengahan 70-an dan mendorong anak-anak muda lain yang bukan penggemar rock ikut membela atau terlibat untuk mendukung nama baik band rock daerahnya maupun reputasi daerahnya. Kabar perkelahian sengit, panas, dan mencekam antar rocker Madura ini terdengar oleh keluarga masing-masing hingga membuat orang tuanya marah besar. Maka, setelah rocker Madura mendapat hukuman keras dari masing-masing keluarganya, para orang tua, jajaran keamanan, dan pimpinan daerah berkumpul di Pamekasan untuk menggelar pentas musik rock perdamaian supaya perkelahian antar rocker Madura tersebut tidak berlarut-larut. Pentas rock ini digelar di pusat kota Pamekasan, di lapangan terbuka depan kantor karesidenan Madura, dan diikuti 2-3 perwakilan band rock dari masing-masing kota di Madura.

Kehidupan musikal anak muda Madura tersebut menunjukkan daya logika mondalitas. Straw (1991) mengkonseptualisasikan logika mondalitas sebagai kemampuan praktek pergerakan dari satu adegan ke adegan lain secara konsisten. Di dalam studi metal, Kahn-Harris (2004: 113) menyebutnya sebagai pengalaman mondalitas karena divergensi gerak yang saling tarikmenarik antara kehidupan di dunia musik metal dan di luar dunia musik metal. Musik metal menciptakan ideologi kepedulian di dua dimensi kehidupan komunitas secara holistik. Yakni, di satu sisi, dimensi mengenai infrastruktur, jaringan, dan praktik musikal, di sisi lain, identitas keanggotaan di ruang komunal yang membukakan batas-batas yang sebelumnya tertutup rapat (Kahn-Harris, 2016: 175-176). Sekalipun demikian, anak muda Madura tidak hanya dipersepsikan atas dasar perspektif tatanan global musik metal dari barat tanpa memperhatikan konteks kemaduraannya.

Selain prinsip tèngka, terdapat tiga dimensi kemaduraan yang sulit hilang dari identitas anak muda Madura. Pertama, anak Madura dikenal sosok pemberani (angko). Sejak kecil, misalnya, anak laki-laki Madura dididik orang tuanya untuk tidak cengeng (birnyi) dan tangguh menghadapi ujian hidup (Wiyata, 2002; Rifai, 2012). Sebelum mempunyai anak sendiri, anak muda Madura dibebaskan mencari pengalaman sebanyak mungkin sebagai bekal hidup setelah mereka menjadi orang tua. Ini bagian dari budaya kaca kebbhâng (cermin pengalaman dialektika antara orang tua dan anak muda) Madura. Karena pengalaman petualangannya mengarungi hidup, mereka disejajarkan dengan orang Cina yang ulet dan suka bekerja keras untuk meraih kesuksesan, baik di Madura atau saat merantau ke kota besar (Santoso, 1994). Pada masa kolonial, anak muda Madura juga terkenal patriotik seperti tercermin dari sejarah perjuangan dan kepahlawanan Pangeran Trunojoyo yang melawan dominasi Mataram akibat bersekongkol dengan rezim kolonial (Kasdi, dkk,. 2003; Kasdi, 2003). Anak muda Madura pun lebih dekat hubungannya dengan identitas pemuda Jawa. Pemuda Jawa tidak seperti analisis kelas konvensional di barat karena, keberanian mereka tidak dipicu oleh situasi perampasan ekonomi dari kelas borjuis, melainkan, atas dasar pencarian makna hidup yang ditopang kekuataan solidaritas, keihlasan, mengamalkan ilmu untuk masyarakat luas, dan gerak hati melihat penderitaan orang lain (Anderson, 1988: 24-25). 
Website : http://sosial.unmermadiun.ac.id/index.php/sosial

Kedua, karena 90\% masyarakat Madura adalah Islam maka, begitu pula anak mudanya. Sejak kecil, anak muda Madura diprioritaskan agar belajar tuntutan Islam, misalnya, rukun Islam dan Iman, sebelum mereka berkenalan dengan sistem pendidikan modern. Islam salah satu sifat penting untuk mendefinisikan jiwa orang Madura seperti ungkapan populer tentang kepercayaannya: asapo' Iman, abhântal Syahadat, apajung Allah (berselimut Iman, berbantal Syahadat, berlindung kepada Allah) (Kusumah, 2003: 21). Para kiai sebagai figur sentral dan ideal di kalangan orang Madura bukan hanya sumber belajar agama, melainkan juga, ikut menyelesaikan berbagai perkara masyarakat yang sulit terpecahkan, sehingga ketundukan terhadapnya merupakan balasan yang tiada bandingnya (Kosim, 2009: 45).

Begitu kuatnya pengaruh ajaran Islam di Madura ini membuat anak mudanya yang bergaya hidup konsumerisme atau boros dianggap mengikuti jalan hidup setan (Rohman, 2016: 238). Kode pakaian anak muda menjadikan pakaian berjenis jeans sebagai bentuk pergeseran representasi kelas sosial, dari kelas pekerja dan masyarakat tradisional di barat menjadi pakaian kelas menengah yang terdidik dan jati diri masyarakat perkotaan di timur (Fiske, 1989: 7). Budaya populer pakaian ini bagi anak muda Madura biasanya dikenakan ketika mereka ke luar rumah untuk menghadiri acara-acara penting di komunitas mereka seperti, berkuliah, perayaan ulang tahun, rapat, dan waktu berkunjung ke rumah teman untuk kegiatan serius atau sekedar ritual berkencan. Bagi anak muda Madura, saat berada di sekitar lingkungan rumah pakaian 'kebesaran' mereka adalah pakaian yang berkode Islami seperti, sarung yang dipadu atasan berjenis kaos maupun kemeja, untuk menampilkan kesan bahwa kehidupan anak muda Madura dengan lika-likunya tidak pernah mencampakkan penanda Islaminya.

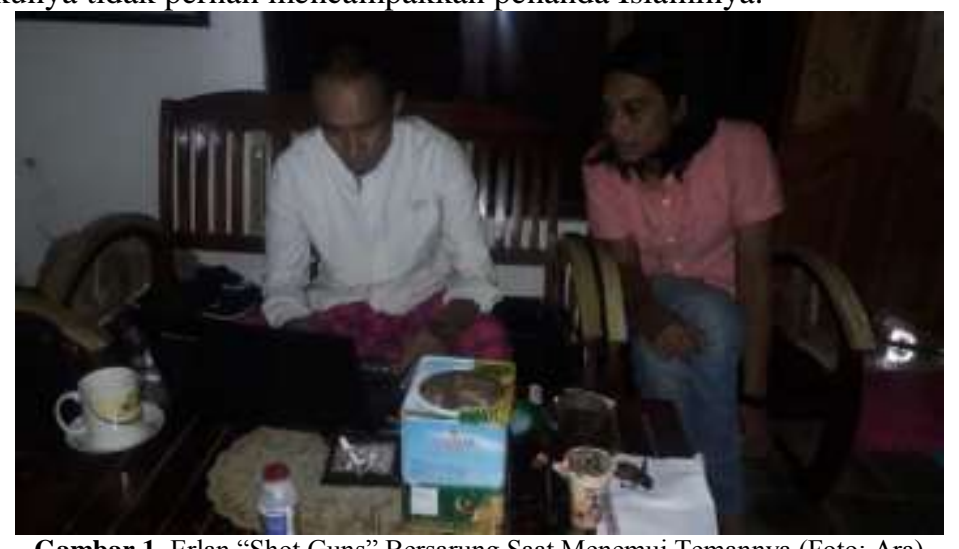

Gambar 1. Erlan "Shot Guns” Bersarung Saat Menemui Temannya (Foto: Ara)

Ketiga, anak muda Madura berbahasa Madura dalam hidup kesehariannya tanpa berbahasa Madura halus (alos) dan bertingkat ( $a$ ondhe'). Dalam percakapan sehari-hari terdapat hirarki bahasa yang dipergunakan orang-orang Madura. Yakni, enjâ-iyâ, èngghi-enten, dan èngghi-bhunten. Bahasa enjâ-iyâ termasuk tingkat bahasa yang rendah. Bahasa ini digunakan dalam pergaulan sesama teman sebaya dan setara posisinya. Bahasa èngghi-enten lebih halus dari bahasa enjâ-iyâ dan digunakan di dalam situasi formal untuk menghargai lawan bicaranya. Bahasa èngghi-bhunten tergolong tingkatan bahasa paling halus. Bahasa halus dipergunakan oleh seseorang apabila berhadapan dengan orang tua Madura. Mereka yang tidak pandai berbahasa halus kepada orang tua Madura akan dianggap jânggâl atau mapas (kurang ajar) (Wiyata, 2002).

Di perkotaan, anak mudanya sering berbahasa Indonesia dengan diselipi kosakata Madura. Sesekali waktu, mencampurkan dengan kosa kata bahasa Inggris secara suka-suka. Karena itu, setiap kongres bahasa Madura seringkali terungkap kekhawatiran punahnya identitas 'otentik' kebahasaan Madura. Intensitas pemakaian bahasa Indonesia yang terlampau besar dalam institusi pendidikan, atau pun perasaan malu mengakui identitas kemaduraan di perkotaan, turut menyumbang rapuhnya kebahasaan orang Madura (Kusnadi, 2008). Contoh tutur bahasa Madura dan penggunaannya di komunitas anak-anak muda pada situasi formal (misalnya, di kelas atau ketika rapat) dan non formal (misalnya, di luar kelas atau di tempat mereka berkumpul) berdasarkan penunjuk diri serta sapaan kepada teman sebayanya setidaknya tergambar jelas dari tabel 2. berikut ini:

Tabel 2. Ragam Tutur Penunjuk Diri dan Sapaan Pertemanan Anak Muda Madura

\begin{tabular}{|c|c|c|c|}
\hline \multirow{2}{*}{ Situasi Penggunaan } & \multicolumn{2}{|c|}{ Contoh Tutur Penunjuk Diri } & \multirow{2}{*}{ Sapaan Pada Teman } \\
\cline { 2 - 3 } & Saya & Kamu & \\
\hline Situasi Formal & Saya/Aku/Engko' & Anda/Saudara/Be'en & Hallo Mas Bro, Hallo Kawan \\
\hline Situasi Non Formal & Saya/Aku/Engko' & Kamu/Nama Julukan/Situh & Hallo Cong, Hallo Trètan \\
\hline
\end{tabular}

\section{B. Kampus 'Metal' Madura dan Politik Anti Politik Anak Metalnya}

Teritorial adegan-adegan musik metal seringkali melibatkan partisipasi kolektif, kesenangan, kesempatan mengekspresikan diri, serta refleksi terhadap kehidupan sekitar. Berdasarkan penelitian Wallach (2011: 85) bahwa salah satu teritorial adegan musik metal di Malaysia sangat marak terjadi di kampus. Di kota-kota besar Indonesia, seperti Jakarta dan Bandung, menurutnya (Wallach, 2008: 140-141) adegan musik metal yang murah meriah berada di tempat nongkrong (hangout), misalnya, di pinggir jalan pusat kota maupun di warung-warung gaul yang memberi kebebasan bagi anak muda bermain musik, bernyanyi, bercanda tawa lepas, dan kesenangan lainnya. Sedangkan, adegan musik metal di komunitas anak metal di Bali terpusat di radio Yudha yang merangkap studio musik (Baulch, 2007: 196-197). Berbeda dengan hasil studi metal Baulch dan 
Website : http://sosial.unmermadiun.ac.id/index.php/sosial

memiliki kesamaan dengan studi metal Wallach, komunitas metal di Madura, terlebih lagi di Pamekasan, kampus maupun sekitar jalan pusat kotanya (area Arek Lancor) adalah teritorial paling penting bagi adegan-adegan kemetalan.

Di area pusat kota Pamekasan menjadi tempat berkumpul komunitas anak metal Pamekasan seperti, PDMS (Pamekasan Death Metal Syndicate). PDMS yang terbentuk secara informal ini kurang lebih terdiri dari 30 anggota aktif dari gabungan antara penggemar dan musisi musik metal. Menurut informasi sebagian anggotanya bahwa terbentuknya PDMS ini sekitar tahun 2010-an silam. Mereka terinspirasi dari komunitas rock yang bersejarah di Pamekasan dan popularitasnya menyebar hingga ke luar Madura, yakni, R 'n R dan Andre Punk pada dekade 2000-an. Tetapi, PDMS tidak bertahan lama karena segala rutinitas berkumpul mereka di sudut jalan pusat kota Pamekasan itu menipis dan berangsur 'hilang total dari peredaran' pasca 2014 silam. Sekeping informasi yang peneliti dapatkan bahwa sebagian anggotanya memutuskan berkeluarga dan hidup di luar kota, dan sebagian lainnya merasa daerahnya telah kehilangan harapan bagi tempat bertumbuh anak-anak mudanya. Sekalipun demikian, PDMS berkontribusi penting bagi kelahiran band metal seperti Roda Hitam, yang pecahan anggotanya membentuk band death metal terkenal, Kill Infection, tahun 2016/2017 silam.

Unira (Universitas Madura) yang berdiri sejak 2 Mei 1978 adalah salah satu kampus tertua dan legendaris di Madura. Kampus ini sering disebut "kampus metal". Sebagian besar rocker, musisi metal, penggemar, dan promotor musik populer di Madura pernah menimba ilmu di kampus Unira. Kelompok rocker dan anak metal di Madura serasa belum lengkap tanpa mencicipi sensasi panasnya panggung musikal di kampus ini. Sejak era 70-an hingga 2000-an, mahasiswa Unira telah menggelar beragam konser dan arena musik spektakuler. Bahkan, musisi rock, pop, dan metal berskala nasional berhasil mereka datangkan ke Madura. Di antaranya, Andromeda, Power Metal, Boomerang, Grand Master, Iwan Fals, Peterpan, Padi, Ungu, Ari Lasso, Duo Kribo, dan masih banyak lagi lainnya. Pasca diberlakukannya politik "Gerbang Salam” (Gerakan Pembangunan Masyarakat Islami) di Pamekasan yang gencar sejak pertengahanan 2000-an, Unira dan sebagian kecil sekolah di Pamekasan menjadi 'surga' terakhir bagi keberlangsungan teritorial beragam adegan musik rock dan metal. Imbas politik "Gerbang Salam" yang paling membahayakan bagi tumbuhnya bakat, minat, dan selera anak muda Madura adalah pengendalian dan 'penghancuran' sistematis eksistensi musik pop, rock, serta metal. Agar tekanan sosial dan psikologis anak muda Madura ini tidak terlampiaskan pada narkoba maka, setahun sekali, saat perayaan hari kemerdekaan R.I (Republik Indonesia) dan ulang tahun Unira, para mahasiswa yang tergabung ke dalam organisasi intra kampus (BEM dan UKM musik) didukung penuh oleh pimpinan kampusnya untuk menggelar rutin beraneka macam pesta musik populernya.

Jujun “Asienk", Fariji, Ahmad Dheni, dan Erlan "Shot Guns” adalah segelintir nama yang biasa bekerja di balik layar untuk mengkemas, membuka jaringan pendanaan, dan mempromosikan nyaris sebagian besar pesta musik populer di Unira. Pada tahun 2018/2019, di kampus Unira terselenggara dua acara besar yang menyedot hingga ribuan penonton dari Madura dan luar Madura. Yakni, acara parade musik "UNIROCK" yang mendatangkan bintang tamu "Power Metal", dan "ANNIVORIA" yang parade musiknya banyak diikuti oleh band-band metal Madura. Tidak seperti gaya adegan kemetalan di kota besar Indonesia seperti, studi metal yang dilakukan Baulch (2007) dan Wallach (2008), atau di negara barat seperti studi metal dari Kahn-Harris (2007), Berger (1999), dan Weinstein (2000), setiap adegan metal di kampus metal Madura ini dipadukan dengan jalan sehat, paduan suara, pertunjukan busana muslim, dan dibuka dengan sambutan seremonial pimpinan kampus, perwakilan pemerintah daerah serta wakil rakyat setempat. Pimpinan kampus, wakil rakyat, dan pemerintah daerah sebagai adegan non kemetalan ini dianggap turut mendukung melalui donasi maupun perijinannya sehingga, mereka perlu diberi panggung minimalis bersuara. Tetapi, sambutan dan suara mereka cenderung membosankan sehingga, hampir tidak ada satu pun anak metal memperhatikannya, kecuali sebagian kecil panitia acara.

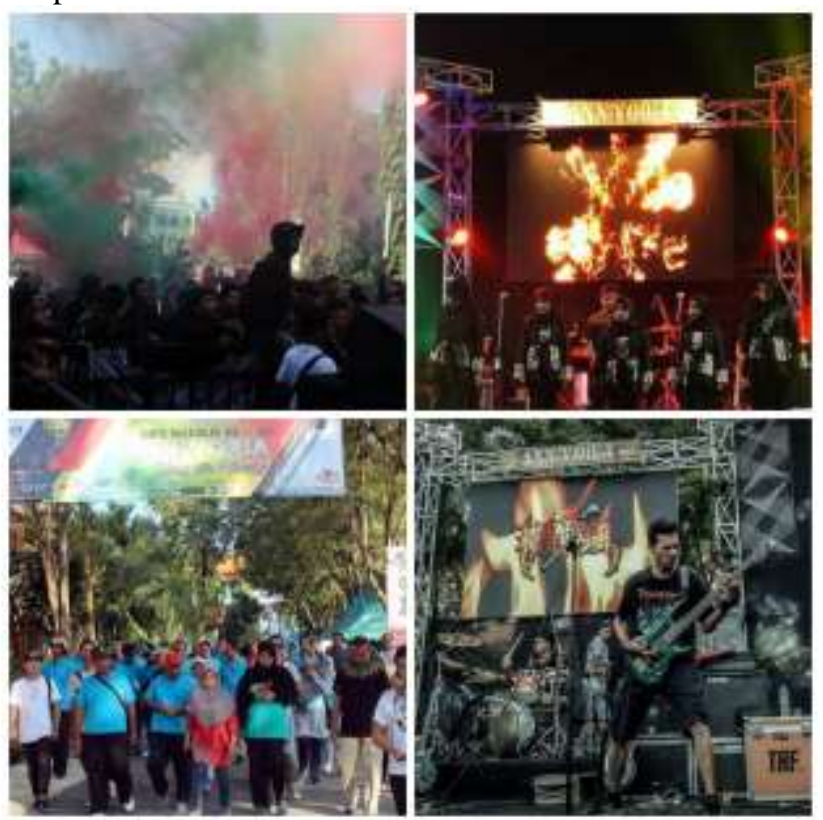

Gambar 2. Suasana Spektakuler "Annivoria” di Kampus Unira (Kolase Foto: Ara) 
Dukungan pendanaan (yang sering diberi suka rela tanpa permohonan resmi) dari kalangan politisi tersebut berguna menambal kekurangan bantuan dana dari sponsor utamanya (misalnya, perusahaan rokok, kartu seluler, dan dealer-dealer otomotif). Untuk itu, di sekitar panggung musik metal, panitia juga menyediakan persewaan murah meriah tenda berukuran kecil sebagai "warung gaul", tempat pemasaran produk olahan mahasiswa dan kalangan usahawan muda dari luar kampus yang baru merintis usaha. Total himpunan dana kasar dari pihak sponsor, donatur, registrasi peserta, dan penyewaan "warung gaul" ini antara 40 - 50 juta. Ironisnya, laba kotor yang diterima panitia hanya berkisar 10\% saja dan dibagi rata dengan belasan jumlah anggota kepanitian. Pendistribusian himpunan dana pesta metal ini disalurkan untuk persewaan panggung dan videotron dari vendor Surabaya (20\%), sounds system dan instrumen musik band di jaringan pertemanan di Madura (10\%), biaya bagi bintang tamu (50\%), serta perijinan, dokumentasi, publikasi, konsumsi hingga akomodasi yang dikelola oleh panitia (20\%). Kepuasan panitia menggelar panggung musik anak muda Madura bukan perkara kalkulasi ekonomi. Orientasi utamanya adalah berusaha mempertahankan eksistensi musikal anak muda Madura yang berada di ambang 'kematian'. Inilah bentuk pertukaran simbolik berganda kelompok subkultur yang berbasiskan logika 'kematian'. Logika 'kematian' menggerakkan pertukaran simbolik antara subjek dan gerak hatinya, kehidupan dan keterasingan, kepatuhan dan perlawanan, sebagai cermin relasi sosial dalam kehidupan abstrak kelompok subordinat (Baudrillard, 2017: 235-236).

Hampir setiap pesta musik anak muda di kampus Unira nama Kill Infection selalu tertera. Kill infection merupakan salah satu band death metal tersohor di Madura. Anggotanya terdiri dari Rian (bass), Jherix (vokal), Ariel (gitar), dan Tony (drum) yang kesemuanya lahir di era 90-an dan alumni Unira. Kabarnya, asal nama band ini terinspirasi dari tradisi 'kebrutalan' dan paling mematikan bagi orang Madura, yakni, carok. Sebab, tradisi carok ini menjalar layaknya virus yang menginfeksi kondisi kesehatan mental dan membunuh akal sehat manusia Madura. Baginya, tradisi carok yang dilakukan para pelakunya menciptakan siklus hidup tidak tertulis yang selalu berakhir balas dendam (nabeng). Aspek penting dari adegan band death metal terdiri dari individualis kritis terhadap kehancuran nilai toleransi, praktik musikal yang memakai ledakan kemarahan untuk menghadapi tekanan hidup, dan menginterupsi kedok kebijaksanaan dalam konsekuensi sosial (Berger, 1999: 267-269). Musik death metal, seperti juga black metal, menandai identitas komunitas genre musikal yang dipinggirkan dan dicampakkan tetapi, para pengusungnya berdiri tegak dalam karakter dualitas, di satu sisi membenci kemunafikan (misantropis), dan mencintai keanggotaannya sebagai kekuataan pertemanan di antara mereka pada sisi lainnya (Scott, 2016: 29).

Mereka juga membenci sentimen keagamaan yang mengekang, tetapi, juga peduli terhadap kemanusiaan, mempropagandakan anti rasisme maupun prasangka negatif, namun juga, mendorong solipisme dan menciptakan metafora destruktif sehingga, budaya metal yang melekat pada adegan kemetalannya sebagai 'adegan berstandar ganda' (Venkatesh, dkk., 2016: 144-145). Kendati begitu, kreativitas dan refleksivitas budaya kemetalan yang paling utama adalah adegan transgresivitas yang mentranformasikan aggresi sosial ke dalam ruang musikalitas, misalnya, lirik, musik, penampilan dan otonomi dirinya, dan deindustrialisasi dunia musik (Kahn-Harris, 2007 dan 2016). Salah satu contoh transgressivitas karya lagu Kill Infection yang popular di komunitas metal di Indonesia adalah carok di album perdananya, "Misanthrophic of Sakera" (dirilis tahun 2017 berbentuk Compact Disk atau CD). Album CD mereka dikelola dan didanai mandiri bersama mitranya di komunitas metal di Indonesia. Dengan memanfaatkan teknologi virtual, seperti internet dan media sosial, CD mereka terjual hingga menembus ke komunitas metal yang ada di Malaysia, Jepang, Norwegia, dan Amerika. Sebagai anak metal yang tergolong pasca subkultur (post-subcultures), mengkoneksikan jaringan online dan offline melalui partisipasi penyeleksian (selecting) serta pencarian (searching) untuk mendistribusikan karya musik, diskursus, dan atribut musik metal merupakan bentuk penghancurkan batasbatas subkultur tradisional (Hodkinson, 2003: 296). Pasca peluncuran album perdana, Kill Infection mulai kebanjiran undangan manggung pada rangkaian gigs berskala nasional di Jakarta, Bandung, dan hampir seluruh daerah pesisir Jawa. Dengan melihat sekilas visualisasi materi CD mereka kita bisa memahami bahwa adegan musik metal yang mereka proklamasikan berdimensi tanda kehidupan manusia yang 'suram, 'kejam', 'ganas', 'brutal', 'tragis', dan 'sadis'. Ledakan amarahnya juga sangat terasa mencolok mata dari lagu “carok”, karena, terselip pesan singkat mereka yang sangat berambisi 'membunuh tradisi' carok secara semiotik, seperti terlihat pada penggalan liriknya berikut ini:

Menggelap mata butakan jiwa rasa tak ingin beri surga

Untuk menebas tubuh menjadi buas

Terasah clurit tajam mumutus saraf

Lalu menikam tubuh lalu potong urat saraf

Carok!!! 
Website : http://sosial.unmermadiun.ac.id/index.php/sosial

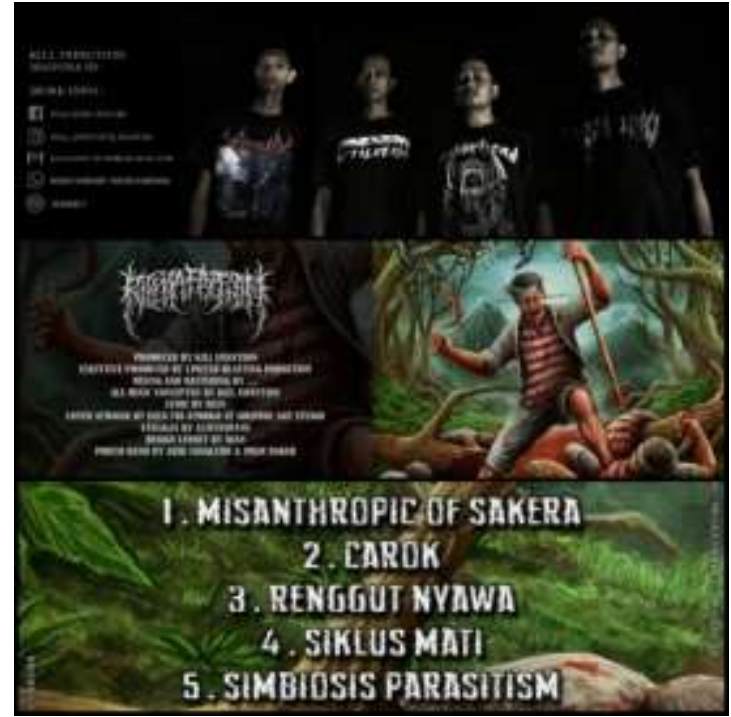

Gambar 3. Cover Album CD Perdana Kill Infection (Kolase Foto: Ara)

Sebagaimana musik rock, musik metal tidak pernah lepas dari gerakan politik budaya. Politik budaya rock tak seperti musik pop. Karena, gaya rocker (seperti, lirik, pakaian, diskursus, musik, dan gerakan protes terhadap pemerintahan yang kejam) bisa memanfaatkan politik momentum sebagai budaya tandingan, dan ini yang berbeda dari politik musik pop yang acapkali mulut musisinya mudah disumpal dengan uang (Redhead, 1990: 13-14). Di Indonesia, komunitas rocker memainkan peranan penting sebagai penyumbang saham jatuhnya rezim otoriterian orde baru. Tetapi, berbeda halnya di Madura, terutama di Pamekasan. Kiai sebagai pemegang otoritas keagamaan (Islam) bisa turut serta terlibat menentukan arah politik di Madura (Abdurrahman, 2009: 25). Mereka juga bukan hanya bisa berperan sebagai broker budaya, namun juga, broker politik yang terkadang dapat mengintegrasikan umat, atau malah juga sebaliknya, memecah belahnya (Geertz, 1960). Pasca orde baru, di kabupaten Pamekasan mengalami penguatan politisasi Islam dengan munculnya gerakan "Gerbang Salam" yang berimbas buruk pada apa pun yang bernafas kebarat-baratan, termasuk, musiknya, sehingga harus 'dilarang' karena mengundang maksiat. Kebijakan "Gerbang Salam" yang digagas melalui pertemuan rutin Ulama-Umara pada tahun 2002 ini menghasilkan kesepakatan pemberlakuan perda Syariah.

Dari empat daerah di Madura, hanya Pamekasan yang ingin menerapkan perda Syariah pada segala aspek kehidupan masyarakatnya. Dengan melibatkan sejumlah akademisi dari kampus Islam, wakil fraksi partai politik, ulama, dan ormas keagamaan setempat maka, terbentuk LP2SI (Lembaga Pengkajian dan Penerapan Syariat Islam) berdasarkan surat keputusan Bupati Pamekasan bernomor 188/126/441.012/2002. Penerapan kebijakan "Gerbang Salam" tersebut meliputi tiga tahap. Mulai dari tahap persiapan program (2002), pelaksanaan dan sosialisasi (2002-2003), hingga pelembagaan dan pembudayaan "Gerbang Salam" (Hariyanto, 2009: 80). Setelah satu dekade kebijakan "Gerbang Salam” berjalan, anak metal berkoalisi dengan aktivitas mahasiswa Unira dan penggemar musik rock di Pamekasan yang tergabung dalam SPSP (Sentral Pencinta Seni Pamekasan). Mereka mengepung gedung DPRD Pamekasan. Mereka menyuarakan protes keras terhadap berbagai upaya pelarangan konser-konser musik anak muda di Pamekasan. Karena mungkin keterikatan politik atau malah takut kualat terhadap para kiai terlalu kuat maka, suara anak muda Pamekasan ini dianggap gonggongan anjing yang hilang dilempar batu. Sebagian orang setempat menengarai bahwa sebagian kiai 'garis keras' yang mendukung atau berafiliasi dengan kelompok FPI (Front Pembela Islam) memperkuat hasrat aggresivitas politik “Gerbang Salam”.

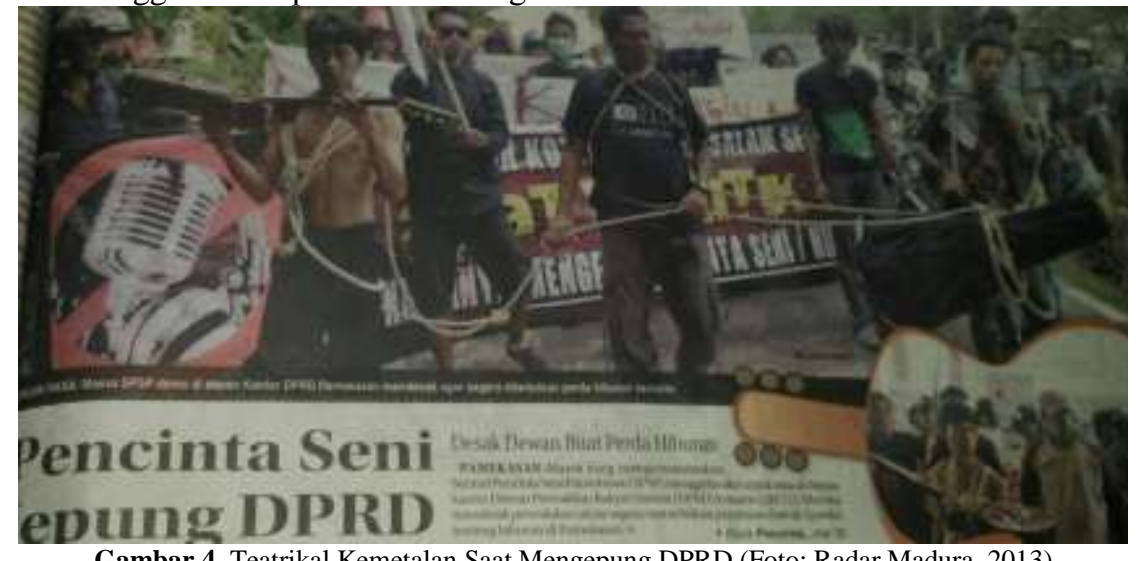

Gambar 4. Teatrikal Kemetalan Saat Mengepung DPRD (Foto: Radar Madura, 2013) 
Kemunculan anak metal baru di Pamekasan, seperti Kill Infection, Jenewer, GFNA, One Band, dan lainnya, pasca lenyapnya SPSP dari diskursus media massa lokal dan ruang akademik di kampus Unira, tidak tertarik dengan segala urusan politik lokalnya. Setiap pemilihan wakil rakyat atau kepala daerah, anak metal baru ini tidak ingin memilih kandidat dari figur agama atau diusung partai-partai Islam. Namun, mereka aktif menyuarakan kepada teman, keluarga dekat, dan jaringan komunitas di luar Madura bahwa masa depan musik metal di Pamekasan telah memasuki masa 'suram'. Kondisi 'suram' ini menjadi energi untuk berkarya menciptakan adegan-adegan kemetalan mereka, baik di dalam maupun di luar Madura. Menurut Lash (1994: 167) komunitas reflektif dalam satu lokasi bisa 'terlempar' ke dalam kelompoknya dan ke luar dari persoalan masyarakat tradisionalnya sehingga, membentuk bentangan ruang berstruktur ganda yang menciptakan praktik kreatif serta problematik. Politik komunitas reflektif sebagai komunitas pasca subkultur ini memainkan politik 'ketidakhadiran' misalnya, menjauh dari pusat politik (Redhead, 1997: 3), dan politik 'kehadiran' dengan memahami situasi empiris (Muggleton, 2000: 10). Atas dasar itu, adegan anak metal terbentuk karena kesadaran diri (reflektif) terhadap persoalan sosial dan kenaifan politik karena purapura tidak tahu terhadap persoalan politik di sekitarnya. Adegan musik metal merepresentasikan adegan reflektif anti reflektif komunitas pasca subkultur (Kahn-Harris, 2007: 144-145). Dengan demikian, anak metal Madura yang tergolong komunitas pasca subkultur sedang memainkan suatu adegan politik anti politik di Madura. Entahlah.

\section{IV.KESIMPULAN}

Kemunculan anak metal Madura dalam dunia musik populer anak muda di Madura memberi makna penting mengenai berbagai persoalan masyarakat Madura yang berbeda dengan masyarakat lain di luar Madura. Kuatnya hirarki sosial yang berimbas terhadap kakunya relasi politik dan budaya antara 'orang tua' Madura dan kesenangan bermusik anak mudanya mendorong anak metal Madura memainkan adegan-adegan musikal bernuansa politis, baik di panggung musik maupun non musikal. Adegan anak metal tersebut tampak spektakuler di sudut-sudut jalan kota dan kampus 'metal'. Tidak seperti studi metal di kota-kota besar, misalnya, Jakarta, Bandung, dan Bali, yang lebih bebas untuk menampilkan beragam adegan kemetalan mereka di ruang-ruang terbuka, anak metal Madura harus berhadapan dengan politisasi agama yang menyasar ke penjuru ruang-ruang terbuka atau juga nilai-nilai tradisional yang menyulut aggresi sosial. Anak metal Madura yang merasa jengah dengan situasi 'bengis' itu melakukan demonstrasi bersama aktivisis mahasiswa yang peduli pada perubahan nasib mereka.

Di sisi lainnya, anak metal Madura generasi baru menjadikan carok sebagai sumber inspirasi mereka dalam memproduksi karya dengan memanfaatkan jaringan komunitas metalnya tanpa harus menghamba pada industri musik. Mereka juga tampaknya berpura-pura tidak peduli pada persoalan politisasi agama yang hingga sekarang ini dianggap ancaman paling 'berbahaya' bagi eksistensi musik anak muda di daerahnya. Tetapi, anak metal Madura yang berpura-pura tidak sadar politik ini justru melakukan penggembosan politisasi agama melalui budaya tandingan di lingkungan pertemanannya. Inilah bentuk kentara politik anti politik, reflektif anti reflektif, sebagai bagian adegan 'tidak kentara' di dunia anak metal Madura.

\section{UCAPAN TERIMA KASIH}

Penelitian ini dilakukan secara singkat ketika masa pandemi Covid-19 menerjang dunia dan Madura. Sebagian data mentahnya sebenarnya telah tersedia pada saat penulis melanglang buana ke seluruh penjuru Madura, sebagian lagi di kota Surabaya dan Malang, untuk menyelesaikan studi doktoral bidang kajian budaya musik populer dan budaya anak mudanya. Setelah 'turun gunung' dan melalui jalan terjal penuh kerikil tajam, muncul fenomena baru di Madura tentang keberadaan anak metal. Itu sebabnya, tulisan ini merupakan 'penghormatan' penulis kepada anak metal Madura yang tergolong generasi baru di Madura pasca orde baru. Terima kasih kepada Kill Infection, Jenewer, One Band, Yayak R 'n R, Sahlan 'Metal', Erlan 'Shot Guns', Ahmad Deni, Fariji, Jujun 'Asienk', Asella Resto, Dinies Cafe, OTW Cafe, IAIN Madura, UNIRA, komunitas OI dan komunitas slanker Madura, Rajam, Megantropus, Mekanik band, Carok Band, Kompas Band, Padi, Power Metal, Grand Master, CB Band, Dewa 19, Bomerang, Rutor, Saltis, dan lain sebagainya (yang tidak cukup disebutkan semua di ruang terbatas ini). Mereka semua dengan caranya sendiri telah memberikan bahan berharga bagi penulis untuk menyusun secara berkala tentang beragam topik musik dan kehidupan anak muda alternatif di Indonesia.

\section{VI.DAFTAR PUSTAKA}

Abdurrahman, 2009. Fenomena Kiai Dalam Dinamika Politik: Antara Gerakan Moral dan Politik (hal. 25-34), KARSA, Vol. XV, No. 1, Pamekasan: STAIN Madura

Anderson, Ben, 1988. Revoloesi Pemoeda: Pendudukan Jepang dan Perlawanan di Jawa 1944 - 1946, Jakarta: Pustaka Sinar Harapan

Bappeda Pamekasan, 2019. Kajian Penelitian Bidang Perekonomian dan Sumber Daya Alam, Pamekasan: Tidak Diterbitkan

Baudrillard, Jean, 2017. Symbolic Exchange and Death (2nd Edition), London: SAGE Publication Ltd.

Baulch, Emma, 2007. Making Scenes: Reggae, Punk, and Death Metal in 1990's Bali, Durham and London: Duke University Press

Becker, Judith, 1975. Kroncong, Indonesia Popular Music (hal. 14-19), Asian Music, Vol. VII, USA: University of Texas Press

Bekcer, S. Howard, 1963. Outsider: Studies in The Sociology of Deviance, London and New York: The Free Press

Bennett, Andy, dan Peterson, A. Richard (ed.), 2004. Music Scenes, USA: Vanderbilt University Press

Berger, M. Harris, 1999. Metal, Rock, and Jazz: Perception and Phenomenology of Musical Experience, London: Wesleyan University Press

Bourdieu, Pierre 1991. Language and Symbolic Power, Cambrige, Massachusetts: Harvard University Press

Bouvier, Hélèna, 1989. Musik dan Seni Pertunjukan di Kabupaten Sumenep, dalam De Jonge, Huub (Ed.), Agama, Kebudayaan, dan Ekonomi, Jakarta: Rajawali Press

Bouvier, Hélèna, 2002. Lèbur: Seni Musik dan Pertunjukan dalam Masyarakat Madura, Jakarta: Yayasan Obor dan Forum Jakarta-Paris 
Website : http://sosial.unmermadiun.ac.id/index.php/sosial

BPS, 2020. Jawa Timur dalam Angka 2020, Surabaya: BPS Jawa Timur

Clarke, John, dkk., 1993. Subcultures, Cultures, and Class: A theoretical overview (hal. 9-74), dalam Hall, Stuart, dan Jefferson, Tony (ed.), Resistance Through Rituals (second edition), UK: CCCS University of Birmingham (this edition published in the Taylor \& Francis e-library, 2003)

Cohen, Albert, 1955. Delinquent Boys: The Culture of The Gang, London: Collier-Macmillan

Cohen, Sara, 2007. Decline, Renewal and the City in Popular Music Culture: Beyond the Beatles, New York \& London: Routledge

Covach, John, 1997. Progressive Rock, "Close to the Edge," and the Boundaries of Style (hal. 3-32), dalam Covach, John dan Boone M., Graeme (ed.), Understanding Rock, New York: Oxford University Press

De Jonge, Huub, 1989. Madura dalam Empat Zaman: Pedagang, Perkembangan Ekonomi, dan Islam, Jakarta: Gramedia

De Jonge, Huub, 2011. Garam, Kekerasan, dan Aduan Sapi, Yogyakarta: LKiS

Falzon Anthony-Mark (ed.), 2009. Multi-Sited Ethnography: Theory, Praxis and Locality in Contemporary Research, England dan USA: Ashgate Publishing Ferzacca, Steve, 2006. Learning How to Listen: Kroncong Music in a Javanese Neighborhood (hal. 331-358), Sense \& Society, Vol. 1, Issue 3, UK: BERG

Fiske, John, 1989. Reading The Popular, Britain: Unwin Hyman (Reprinted Routledge: New York \& London)

Flick, Uwe, 2007. Designing Qualitative Research, London: SAGE

Frederick, H., William 1982. Rhoma Irama and The Dangdut Style: Aspects of Contemporary Indonesian Popular Culture (hal. 102-130), Indonesia, Vol. 34, USA: Cornel University Press

Fromm, Erich, 1973. The Anatomy of Human Destructiveness, New York, Chicago, and San Francisco: Holt, Rinehart and Winston

Geertz, Clifford, 1960. The Javanese Kijaji: The Changing Role of A Cultural Broker (hal. 228-249), Comparative Studies in Society and History, Vol. 2, No. 2

Grossberg, Lawrence, 1997. Another Boring Day in Paradise: Rock and Roll and The Empowerment of Everyday Life (hal. 477-493), dalam Gelder, Ken, dan Thornton, Sarah (ed.), The Subcultures Reader, London and New York: Routledge

Hariyanto, Erie, 2009. Gerbang Salam: Telaah Atas Pelaksanannya di Kabupaten Pamekasan (hal. 73-81), KARSA, Vol. XV, No. 1, Pamekasan: STAIN Madura Hebdige, Dick, 1979. Subculture: The Meaning of Style, London: Routledge

Hebdige, Dick, 1997. Posing ... Threats, Striking ... Poses: Youth, Surveillace, and Display (hal. 393-405), dalam Gelder, Ken, dan Thornton, Sarah (ed.), The Subcultures Reader, London and New York: Routledge

Hodkinson, Paul, 2002. Goth: Identity, Style and Subculture, Oxford: Berg

Kahn, Keith-Harris, 2004. Unspectacular Subculture? Transgression and Mundanity in The Global Extreme Metal Scene (hal. 107-118), dalam Bennett, Andy, dan Harris-Keith Kahn (ed.), After Subculture: Critical Studies in Contemporary Youth Culture, New York: Palgrave Macmillan

Kahn, Keith-Harris, 2007. Extreme Metal: Music and Culture on The Edge, New York: Berg

Kahn, Keith-Harris, 2016. Do Metal Scenes Need Retirement Homes?: Care and the Limitations of Metal Community (hal. 171 - 184), dalam Varas, NelsonDiaz, dan Scott, Niall (ed.), Heavy Metal Music and the Communal Experience, Lanham, Boulder, New York, dan London: Lexington Books

Kasdi, Aminuddin, 2003. Perlawanan Penguasa Madura Atas Hegemoni Jawa, Yogyakarta: Jendela

Kasdi, Aminuddin, dkk., 2003. Sejarah Perjuangan Raden Trunajaya, Surabaya: Unesa University Press

Konrad, Lorenz, 2002. On Aggression, London and New York: Routledge

Kosim, Mohammad, 2009. Kiai di Persimpangan Jalan: Antara Pesantren dan Politik (hal. 44-52), KARSA, Vol. XV, No. 1, Pamekasan: STAIN Madura

Kuntowijoyo, 1993. Radikalisasi Petani, Yogyakarta: Bentang

Kuntowijoyo, 1995. Madura for Sale? (hal. 195-208), dalam Van Dijk, Kees, dkk. (ed.), Across Madura Strait: The Dynamic of an Insular Society, Leiden KITLV

Kuntowijoyo, 2002. Perubahan Sosial dalam Masyarakat Agraris Madura (1850-1940), Yogyakarta: Mata Bangsa

Kusnadi, 2008. Strategi Pelestarian dan Pengembangan Bahasa dan Sastra Madura, Pamekasan: panitia kongres Bahasa Madura I

Kusumah, Surya, Maulana, 2003. Sopan, Hormat, dan Islam: Ciri-Ciri Orang Madura (hal. 1-29), dalam Soegianto (ed.), Kepercayaan, Magis, dan Tradisi dalam Masyarakat Madura, Jember: Penerbit Tapal Kuda

Last, Scott, 1994. Reflexivity and its Double Structure, Aesthetic, Community, dalam Beck, Ulrich, Giddens, Anthony, dan Lash, Scott, Reflexive Modernization: Politics, Tradition, and Aesthetic in The Modern Social Order, Cambridge: Polity Press

Maxwell, A. Joseph, 2013. Qualitative Research Design, London: SAGE

Mazzoni, Augusto, 2010. Music (Hal. 223-230) dalam Sepp, R.H, and Embree L. (ed.) Handbook of Phenomenological Aesthetics, USA: Springer

McRobbie, Angela, 1989. Second Hand Dresses and The Role of The Rag Market, dalam McRobbie, Angela (ed.), Zoot Suits and Second Hand Dresses: An Anthology of Fashion and Music, London: Macmillan

Monelle, Raymond, 1992. Linguistics and Semiotics in Music, UK: Harwood academic Publisher

Mrázek, Jan, 1999. Javanese Wayang Kulit in The Times Comedy: Clown Scenes, Innovation, and The Performance's Being in The Present World (hal. 38128), Indonesia, 68, USA: Cornell University Press

Muggleton, David, 2000. Inside Subculture: The Posmodern Meaning of Style, Oxford: BERG

Pemerintah Pamekasan, 2010. Ensiklopedi Pamekasan, Pamekasan: Pemkab Pamekasan dan FIB UGM

Purcell, J. Natalie, 2003. Death Metal Music: The Passion and Politics of a Subculture, Jefferson, North Carolina \& London: McFarland \& Company, Inc. Publisher

Raditya, Ardhie, 2016. Produksi Budaya Madura di Pamekasan, Pamekasan: Bappeda dan Litbang Kedai Kopi 11/12

Raditya, Ardhie, 2019. Rute Kultural Musik Populer Di Madura (hal. 68-84), Jurnal Penelitian Ilmu-Ilmu Sosial, Vol. 20, Nomor 2

Raditya, Ardhie, 2020. Karakter Orang Madura, Nasionalisme, dan Globalisasi (hal. 15-33), Masyarakat Indonesia, Vol. 46, No. 1

Redhead, Steve, 1990. The End-of-The Century Party: Youth and Pop Toward 2000, New York and Manchester: Manchester University Press

Redhead, Steve, 1997. Post-Fandom and The Millenial Blues, London and New York: Routledge

Rifai, A. Mien, 2012. Memadurakan Memuda Madura Menjadi Manusia Idaman Abad XXI, Sumenep: Makalah Kongres Kebudayaan Madura II

Rohman, Abdur, 2016. Budaya Konsumerisme dan Teori Kebocoran di Kalangan Mahasiswa (hal. 237-253), KARSA, Vol. 24, No. 2, Pamekasan: STAIN Madura

Santoso, Thomas, 1994. Prilaku Kerja Pialang Tembakau, Surabaya: Pasca Sarjana Unair

Scott, Niall, 2016. Absurd Communities of Misanthropic Paradox Destruction: You Play and We'll Destroy The House (hal. 23-36), dalam Varas, Nelson-Diaz, dan Scott, Niall (ed.), Heavy Metal Music and the Communal Experience, Lanham, Boulder, New York, dan London: Lexington Books

Shank, Barry, 1994. Dissonant Identities: The Rock 'N' Roll Scene in Austin, Texas, Hanover \& London: Wesleyan University Press

Shuker, Roy, 1994. Understanding Popular Music, London and New York: Routledge

Straw, Will, 1991. Systems of Articulation, Logics of Change: Scenes and Communities in Popular Music (hal. 361-375), Cultural Studies, Vol. 5, No. 3

Straw, Will, 2004. Cultural Scenes (hal. 411-422), Society and Leisure, Vol. 72, No. 2

Thornton, Sarah, 1995. Club Culture: Music, Media, and Subcultural Capital, UK: Politiy

Thornton, Sarah, 1997. General Introduction (hal. 11-15), dalam Gelder, Ken, dan Thornton, Sarah (ed.), The Subcultures Reader, London and New York: Routledge

Venkatesh, dkk., 2016. Exploring The Language and Spectacle of Online Hate Speech in The Black Metal Scene (hal. 127-150), dalam Varas, Nelson-Diaz, dan Scott, Niall (ed.), Heavy Metal Music and the Communal Experience, Lanham, Boulder, New York, dan London: Lexington Books

Wallach, Jeremy, 2008. Modern Noise, Fluid Genres: Popular Music In Indonesia, Madison: The University of Winconsin Press 
Website : http://sosial.unmermadiun.ac.id/index.php/sosial

Wallach, Jeremy, 2011. Unleashed in The East Metal Music, Masculinity, and "Malayness" in Indonesia, Malaysia, and Singapore (hal. 85-105), dalam Wallach, Jeremy, Berger, M. Harris, dan Greene, D. Paul (eds.), Metal Rules The Globe: Heavy Metal Music Around The World, Durham \& London: Duke University Press

Wallach, Jeremy, Berger, M. Harris, dan Greene, D. Paul, 2011. Affective Overdrive, Scene Dynamics, and Identity in The Global Metal Scene (hal. 1-33), dalam Wallach, Jeremy, Berger, M. Harris, dan Greene, D. Paul (eds.), Metal Rules The Globe: Heavy Metal Music Around The World, Durham \& London: Duke University Press

Weinstein, Deena, 2000. Heavy Metal: The Music and Its Culture (Revised Edition), Boston: De Capo Press

Willis, Paul, 2014. Profane Culture, United Kingdom: Princeton University Press

Witkin, W. Robert, 2003. Adorno on Popular Culture, London and New York: Routledge

Wiyata, Latief, 2002. Carok: Konflik Kekerasan dan Harga Diri Orang Madura, Yogyakarta: LKiS

Yampolsky, Philip, 1991. Indonesian Popular Music: Keroncong, Dangdut, and Langgam, Music of Indonesia Series 2, Washington DC: Smithsonian/Folkways CD SF 40056

Young, Jock, 1997. The Subterranean World of Play (hal. 71-82), dalam Gelder, Ken, dan Thornton, Sarah (ed.), The Subcultures Reader, London and New York: Routledge

Zahn-Waxler, dkk. (ed.), 1986. Altruism and Aggression: Biological and Social Origins, Cambride: Cambride University Press 